\title{
Electrochemical Biosensor for Mitochondrial DNA of Sus Scrofa Detection Using A Cerium-Modified Screen Printed Carbon Electrode
}

\author{
Maulida Fajriyah ${ }^{1}$, Yusuf Rohmatulloh ${ }^{2}$, Shabarni Gaffar ${ }^{3}$, Anni Angraen $^{4}$, Yeni Wahyuni \\ Hartat $^{5}$ \\ \{maulida17002@mail.unpad.ac.id ${ }^{1}$, yusufrohmatullah@uinsgd.ac.id², shabarni.gaffar@unpad.ac.id ${ }^{3}$, \\ anni.anggraeni@unpad.ac.id ${ }^{4}$,yeni.w.hartati@unpad.ac.id ${ }^{5}$, \\ Department of Chemistry, Faculty of Mathematics and Natural Sciences, Universitas \\ Padjajaran Indonesia ${ }^{1,2,3,4,5}$
}

\begin{abstract}
Cerium is one of the rare elements with high abundance and has been widely used in sensor applications. In this study, electrochemical DNA biosensor has been developed to detect mitochondrial DNA (mtDNA) of Sus scrofa using a screen-printed carbon electrode-cerium (SPCE-Ce). The surface of the SPCE electrode before and after modification with cerium was characterized using scanning electron microscopy (SEM) and cyclic voltammetry. The design of the pig nucleotide sequence as probe DNA was determined using NCBI blast and t-coffee programs. The probe DNA was immobilized onto SPCE-Ce through electrostatic interactions between the cerium surface and the phosphate backbone of DNA. Furthermore, the hybridization probe-target DNA process was characterized using voltammetry differentiation pulse (DPV). The SPCE and SPCE-Ce surfaces in SEM show morphological differences, which are smoother and uniform surfaces after the carbon surface is covered by cerium. The cyclic voltammograms showed a redox current peak rise from the electroactive ferric cyanide species at SPCECe. The probe sequence is 5'-TATTIATACCAATCACTAIC-3' has an identity of $100 \%$ with cytochrome b (Cyt b) mtDNA of Sus scrofa. Hybridization probetarget DNA characterized using voltammetry produce peak oxidation of guanine range potential to be at $1.20 \mathrm{~V}$ to $1.22 \mathrm{~V}$. The optimum experimental conditions were carried out at $30.0 \mu \mathrm{g} / \mathrm{mL}$ for probe concentration, 20 minutes for immobilization time, and 20 minutes for hybridization time. The linear equation of the target concentration against was $\mathrm{I}=0.0303$ [target] +3.947 for the target DNA concentration range 5.0 to $30.0 \mu \mathrm{g} / \mathrm{mL}$. Determination of analytic parameters showed that the values of sensitivity, LoD, LoQ, and precision were $0.0303 \mu \mathrm{g} / \mathrm{mL}, 1.44 \mu \mathrm{g} / \mathrm{mL}, 4.81 \mu \mathrm{g} / \mathrm{mL}$, and $98.99 \%$, respectively. This biosensor can be used to determine pig mtDNA concentrations in real samples.
\end{abstract}

Keywords: Sus scrofa, SPCE-Ce, electrochemical DNA biosensor, differential pulse voltammetry. 


\section{Introduction}

Food is the most basic need of humans so that safety and halal factors of food products are very much concerned by consumers [1]. Halal label manipulation is often committed by attaching illegal halal labels of the Food, Drug, Cosmetics and Beverage Supervision Institute - Indonesian Ulema Council (LPPOM MUI) [2]. One of the problems often found in non-halal food is the presence of pig contents in various types of food products. The increasing activity of adding pig contents to food products has challenged researchers to find a fast and simple method in detecting the presence of pig contents in food products [3]-[8].

In the last few years, the use of electrochemical DNA biosensors has been very rapid due to interesting advantages, such as, its simplicity, economic, rapid detection, high sensitivity, the potential for detection (both DNA, RNA and protein), and can be used as portable devices [9], [10]. The principle of electrochemical DNA analysis is based on the hybridization of probes DNA sequence with their complementary strands that have high efficiency and specificity [9]. DNA based analysis method is effective considering the good stability of DNA reaction to heat, making it possible to use it in the analysis of processed food products that undergo a heating process. Also, extraction of DNA can be taken from all types of tissue since every cell contains DNA [11].

In cells, the nucleus and mitochondria are two locations for the existence of DNA. Mitochondria are one of the most abundant organelles in cells. DNA that is inside the mitochondria is called mitochondrial DNA. The sequence of mitochondrial DNA (mtDNA) of a species is very distinctive one to another. A sequence of cytochrome b gene (Cyt b) and Dloop region are the parts of mitochondrial DNA which are very variable, so it can be used to distinguish species [12]. Several studies have analyzed specific sequences of pig mitochondrial DNA [13]-[16]. Other research has been carried out to identify pig contents using biosensors, namely nanobioprobe for pork identification in burgers [17], optical nanobiosensor for detection and quantification of pig DNA in mixed meat [18], detection of pig DNA with $\left[\mathrm{Ru}(\mathrm{bpy})_{2}(\mathrm{PIP})\right]^{2+}$ complex [19], voltammetric biosensors using SPCE-reduced graphene oxide electrode [20], and voltammetric biosensors using SPCE-AuNP [21].

Cerium is one of the abundant materials of rare earth elements which has attracted great attention in recent years due to its unique characteristics such as physical and chemical properties that are different from other materials, mechanical stability, high electronic conductivity, non-toxic, high isoelectric point (9.2), and biocompatibility [22]. Some cerium carbonate, -phosphate, -silicate and -oxide minerals have been mined and historically processed for pharmaceutical and industrial applications. Cerium has also been used in various fields of engineering and technology that demand high sensitivity detection, one of which is the development of electrochemical biosensors [23].

In biosensor systems, cerium can be used in all parts of the sensor or the recognition part of the transducer elements. Some studies on the use of cerium, in the form of nanoparticles, as sensors have been widely published, both DNA sensors and antibodies. They have tested the sensitive effects of $\mathrm{CeO}_{2}$ from the immunosensor-based ISFET (Ion Sensitive Field Effect Transistor) to detect Salmonella by synthesizing the $\mathrm{CeOx}$ layer through evaporation and oxidation of cerium diffusion furnaces at $250^{\circ} \mathrm{C}$ in oxygen [24]. The results showed that the concentration of hydrogen protons could shift ISFET voltage limit and increase sensitivity and stability of immunosensors when silicon nitrate was replaced with $\mathrm{CeO}_{2}$ on the surface of the transducer.

Cerium is also a new strategy in synthesizing DNA-based biosensors. Cerium immobilizes DNA probes through electrostatic interactions between their surfaces and the 
phosphate backbone of DNA [25]. In the biomedical field, nano cerium is widely used as a drug delivery system, antioxidant, and detection of various diseases. The research report on DNA-based electrochemical biosensors using chitosan bioconjugate coated with $\mathrm{CeO}_{2} \mathrm{NP}-$ MWNT-AuNP/DNA probes for BCR/ABL fusion gene detection in chronic myelogenous leukemia states that using $\mathrm{CeO}_{2} \mathrm{NP}$ can increase peak current measurements by up to 12 times higher and get the lowest detection limit of $5 \times 10^{-3} \mathrm{M}[23]$. While in the field of food science, cerium sensors can be used to detect halal or health insurance of food products. conducted a study of sensor sensitivity based on nanorod cerium oxide to detect the presence of Salmonella bacteria in food products [22]. The results showed that the detection limit obtained was 0.01 $\mu \mathrm{M}$ from the target DNA concentration range of $0.01 \mu \mathrm{M}$ to $2.0 \mu \mathrm{M}$ and the sensor could be used as a portable detector. However, the use of cerium as a sensor to detect pig DNA has not been done.

In addition to paying attention to materials used in biosensors, determination of probe DNA sequences also needs to be considered. The basis for determining the probe DNA sequence is that the base sequence of the probe is assumed to have similarities to the base sequence of the target so that probe DNA can hybridize with the target DNA. The hybridization process will show a measurement response in the form of peak current. The probe DNA was designed using the NCBI blast and t-coffee program. NCBI blast is a collection of DNA and protein databases of all types of living creatures, while t-coffee is a program to determine the percentage of similarity between two or more DNA sequence data and can determine a sustainable area in that sequence [26].

In this study, electrochemical DNA biosensors using cerium modified SPCE were used to detect Sus scrofa mitochondrial DNA. This method is very good as an alternative way of detecting pig DNA contained in processed meat and food products. This proposed method can be used as a portable detection kit.

\section{Materials and Methods}

\subsection{Materials}

Pig DNA probe 5'-TATTIATACCAATCACTAIC-3' and DNA complementary 5'GCTAGTGATTGGTATCAATA-3' (Integrated DNA Technologies Singapore, PT Genetika Science Indonesia), cerium (IV) sulphate tetrahydrate $\left(\mathrm{Ce}\left(\mathrm{SO}_{4}\right)_{2} .4 \mathrm{H}_{2} \mathrm{O}\right)$, sodium hydroxide $(\mathrm{NaOH})$, phosphate buffer saline (PBS) $\mathrm{pH} 7.4$, acetate acid $\left(\mathrm{CH}_{3} \mathrm{COOH}\right)$ glacial (Merck, Jerman), sodium acetate trihydrate $\left(\mathrm{CH}_{3} \mathrm{COONa} .3 \mathrm{H}_{2} \mathrm{O}\right)$, sulphate acid $\left(\mathrm{H}_{2} \mathrm{SO}_{4}\right)$, potassium ferric cyanide $\left(\mathrm{K}_{3}\left[\mathrm{Fe}(\mathrm{CN})_{6}\right]\right)$, aqua pro injection (PT Ikapharmindo Putramas, Jakarta).

Zimmer and Peacock was connected to the computer using PSTrace 5.4 software, scanning electron microscopy (SEM) (JSM-6360-LA), screen-printed carbon electrode (SPCE) (GSI Technologies, USA), centrifugator (Thermo Scientific MicroCL 17R, USA), mini spin (Eppendorf), autoclave sterilizer (Prestige Medical Series 2100), balance scales (Mettler Toledo AL204), hot plate (IKA C-MAG HS 7), magnetic stirrer, micro pipets, microtube (Eppendorf), and micro pipets (MF Lab, Indonesia).

\subsection{Design of DNA sequences of Cyt b Sus scrofa}

The probe DNA sequence was designed using NCBI software through the BLAST ${ }^{\circledR}$ (Basic Local Alignment Search Tool ${ }^{\circledR}$ ) and t-coffee methods. In the search for the Cyt b gene in the pigs, the cursor was directed to search column and nucleotide menu was selected, then 
the keyword 'cytochrome b Sus scrofa' was entered. Running of the search for the Cyt b gene took a few moments, then data will be obtained in the form of gene identification numbers, location of the intended sequence, and other data related to the Cyt gene $b$.

The sequence alignment was then performed using NCBI-Blast to find out the identity of the desired sequence/probe. On this page, Nucleotide BLAST box was clicked and pig probe sequence was entered, BLAST then was clicked. The same treatment was carried out for cyt $b$ chicken and beef to find out the percentage of both homologies with pork. The next step was the alignment of 3 sequences through t-coffee server. On the home page, the DNA menu in the dialogue box was clicked, and M-coffee was selected. The third sequence then was copied in the box provided, to give a boundary between sequences, the "> sequence name " sign was used and entered, then submitted.

\subsection{Preparing $\mathrm{Ce}\left(\mathrm{SO}_{4}\right)_{2} 100 \mathrm{ppm}$ solution}

$1.45 \mathrm{mg} \mathrm{Ce}\left(\mathrm{SO}_{4}\right)_{2} \cdot 4 \mathrm{H}_{2} \mathrm{O}$ was dissolved in 10 drops of $0.2 \mathrm{M} \mathrm{H}_{2} \mathrm{SO}_{4}$. Aqua pro injection was then added until the volume was $10.0 \mathrm{~mL}$. The solution was stirred and heated at $60-70^{\circ} \mathrm{C}$ using a magnetic stirrer and hot plate for \pm 5 minutes.

\subsection{Preparing acetate buffer solution}

Solid sodium acetate trihydrate was weighed 34.0216 grams, then dissolved with aqua pro injection. Into the solution, drop-wise of glacial acetic acid was added until $\mathrm{pH}$ 5.0. After that, an aqua pro injection was added until the volume of the solution was $500 \mathrm{~mL}$, and $0.5 \mathrm{M}$ acetate buffer solution $\mathrm{pH} 5.0$ was obtained.

\subsection{Preparing phosphate buffer solution}

PBS solution $\mathrm{pH} 7.4$ was prepared by dissolving $2.0016 \mathrm{~g} \mathrm{NaCl}(137 \mathrm{mM}), 0.5032 \mathrm{~g} \mathrm{KCl}$ (27 mM), $0.3857 \mathrm{~g} \mathrm{Na}_{2} \mathrm{HPO}_{4}(4.3 \mathrm{mM})$ and $0.0610 \mathrm{~g} \mathrm{KH}_{2} \mathrm{PO}_{4}$ with aqua pro injections in a $250 \mathrm{~mL}$ volumetric flask. The $\mathrm{pH}$ of the solution is then adjusted by adding a $0.1 \mathrm{M} \mathrm{NaOH}$ solution until $\mathrm{pH} 7.4$.

\subsection{Pretreatment of electrode}

The SPCE was pretreated in $0.05 \mathrm{M}$ acetate buffer $\mathrm{pH} 5.0$ and applied potential of $+1.4 \mathrm{~V}$ at scanning rate of $0.1 \mathrm{~V} / \mathrm{s}$.

\subsection{Modification of SPCE surface with cerium}

Pretreated SPCE was dropped with $\mathrm{Ce}\left(\mathrm{SO}_{4}\right)_{2} 5.0 \mathrm{mg} / \mathrm{L}$ and electrodeposition was carried by the differential pulse voltammetry (DPV) with a potential range of $-2.57 \mathrm{~V}$ to $+1.176 \mathrm{~V}$ with a scanning rate of $0.1 \mathrm{~V} / \mathrm{s}$. After that, the electrode was rinsed carefully with aqua pro injection and dried at room temperature. Modified SPCE was characterized using cyclic voltammetry $(\mathrm{CV})$ with a redox $\mathrm{K}_{3}\left[\mathrm{Fe}(\mathrm{CN})_{6}\right]$ system in the potential range of $-0.8 \mathrm{~V}$ to $+0.8 \mathrm{~V}$ and a scanning rate of $50 \mathrm{mV} / \mathrm{s}$. 


\subsection{Immobilization of probe DNA}

$40 \mu \mathrm{L}$ DNA probes were dropped onto the SPCE-Ce surface for 20 minutes by variation of time and concentration of probe DNA.

\subsection{Hybridization of target DNA with probe DNA}

Hybridization of probe-target DNA was carried out by variation of time and concentration of target DNA.

\subsection{Optimization of the experimental conditions}

The factors that influence the experiment were chosen as factors to be optimized. In this study, 3 factors were selected, namely probe concentration, immobilization time, and hybridization time, as can be seen in Table 1 .

Table 1. Factors that influence the experiment.

\begin{tabular}{lclc}
\hline \multicolumn{1}{c}{ Factor } & Level & Unit \\
\hline Consentration of probe & $5.0,10.0,20.0$, and & $\mu \mathrm{g} / \mathrm{mL}$ & \\
& 30.0 & Minute & Minute \\
Immobilization time & 10 and 20 & & \\
Hybridization time & 10 and 20 & & \\
& & & \\
\hline
\end{tabular}

\subsection{Determination of DNA biosensor response to target DNA}

Cerium modified SPCE was rinsed with $0.05 \mathrm{M}$ acetate buffer $\mathrm{pH} 5.0$, then $40 \mu \mathrm{L}$ probe DNA was dropped onto the surface of the electrode for 20 minutes. Then rinsed with $0.05 \mathrm{M}$ acetate buffer $\mathrm{pH}$ 5.0. After that, the electrode was dropped with $40 \mu \mathrm{L}$ of target DNA for 20 minutes. The signal is observed differential voltammetry pulses in the potential range between $-0.2 \mathrm{~V}$ to $+1.4 \mathrm{~V}$ with a scanning rate of $0.008 \mathrm{~V} / \mathrm{s}$. The electrochemical biosensor fabrication scheme for detecting pig DNA is shown in Figure1.

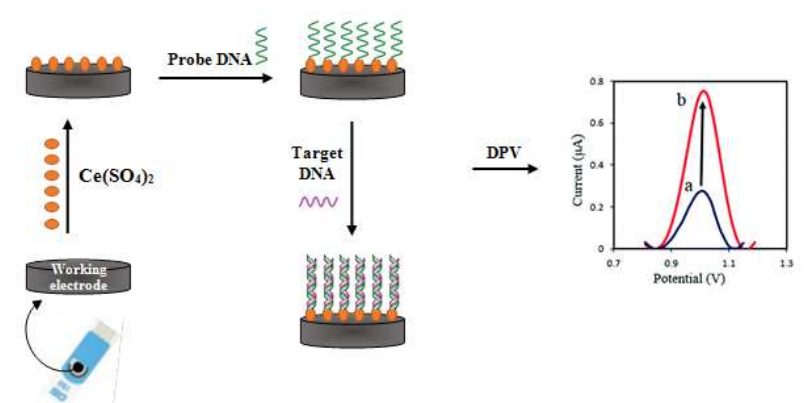

Figure 1. Electrochemical biosensor fabrication scheme for Sus scrofa DNA detection. 


\section{Result and Discussion}

\subsection{Design of DNA sequences of Cyt b Sus scrofa}

NCBI is a source of information for molecular biology development, which creates databases for genomic, proteomic and metabolomic data from various organisms. The nucleotide sequence data presented in NCBI can be in the form of pasta or common sequential forms. The sequence of probes that are designed must have an identity value of $100 \%$, meaning that probes DNA can complement the target DNA sequence. The probe DNA sequence must also have $0 \%$ homology, which means that it only binds specifically to the target DNA sequence. The results of the analysis with BLAST ${ }^{\circledR}$ and t-coffee are presented in Table 2.

Table 2. Data analysis results with BLAST ${ }^{\circledR}$ and t-coffee

\begin{tabular}{ccccc}
\hline Sequence of probe DNA & $\begin{array}{c}\text { Sequenc } \\
\text { e in Gen } \\
\text { Bank }\end{array}$ & $\begin{array}{r}\Sigma \\
\text { bases }\end{array}$ & $\begin{array}{c}\text { Ident } \\
\text { ities (\%) }\end{array}$ & $\begin{array}{c}\text { Homol } \\
\text { ogy (\%) }\end{array}$ \\
\hline $\begin{array}{c}1091- \\
\text { TATTGATACCAATCACTAGC-3 }\end{array}$ & $\begin{array}{c}1110 \\
0\end{array}$ & 100 & 0 \\
\hline
\end{tabular}

The voltammetric biosensor uses a 20 mer probe as a bioreseptor or identifiable compound that will hybridize with the target DNA. The sequence of probes is a sequence in the Sus scrofa gene from 1091 to 1110 . In this study, hybridization techniques without indicators were used so that guanine in the probe was replaced with inosine. Inosine has characteristics similar to guanine, which can hybridize with cytosine. However, inosine does not provide an electrochemical response in the form of an oxidation signal in a potential area of guanine. When the probe-target DNA hybridization occurs, only the oxidation signal is observed based on the guanine oxidation response on the target.

\subsection{Modification of SPCE surface with cerium}

SEM images and the result of cyclic voltammograms for SPCE before and after cerium modification are shown in Figure 2. 

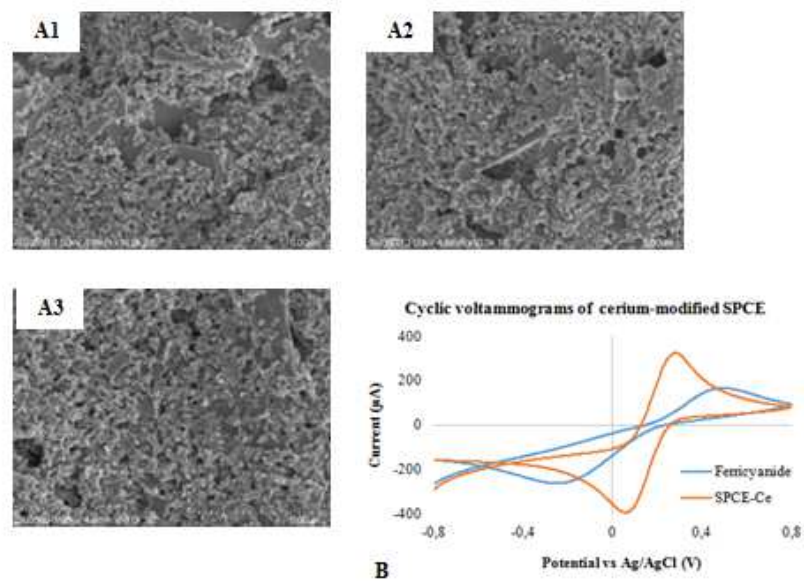

Figure 2. (A) SEM images of (1) SPCE bare, (2) SPCE - Ce, and (3) SPCE - Ce - probe; (B) cyclic voltammogram as a results of SPCE characterization before and after modification with cerium based on $20 \mathrm{mM} \mathrm{K}_{3}\left[\mathrm{Fe}(\mathrm{CN})_{6}\right.$ in $0.1 \mathrm{M} \mathrm{KCl}$ redox system with a scanning rate of $0.1 \mathrm{~V} / \mathrm{s}$ in the potential range of $0.8 \mathrm{~V}$ to $+0.8 \mathrm{~V}$.

Figures 2 A1-A3 show differences in the SPCE bare electrode surface, SPCE-Ce, and SPCE-Ce-probe. In SPCE bare pieces like rectangles are seen, it is suspected that the piece is a carbon material which is the basic material of SPCE. Whereas on SPCE-Ce and SPCE-Ceprobes, the electrode surface is smoother and uniform. Figure $2 \mathrm{~B}$ shows the results of characterization using cyclic voltammetry which shows that SPCE-Ce results increase the peak current oxidation and reduction of the electroactive species of ferric cyanide. This increase in peak oxidation-reduction current occurs because cerium has been electrodeposition on the SPCE surface, increasing electrochemical activity which is proportional to the increase in the active area of the electrode. Cerium is very conductive which contributes to electron transfer on the surface of the electrode so that this electrodeposition can increase the sensitivity of the electrochemical sensor.

\subsection{Immobilization of probe DNA and hybridization probe-target DNA}

Measurement of guanine oxidation signals on SPCE-Ce for probes DNA, target DNA, and hybridization of probes-target DNA are shown in Figure 3. 


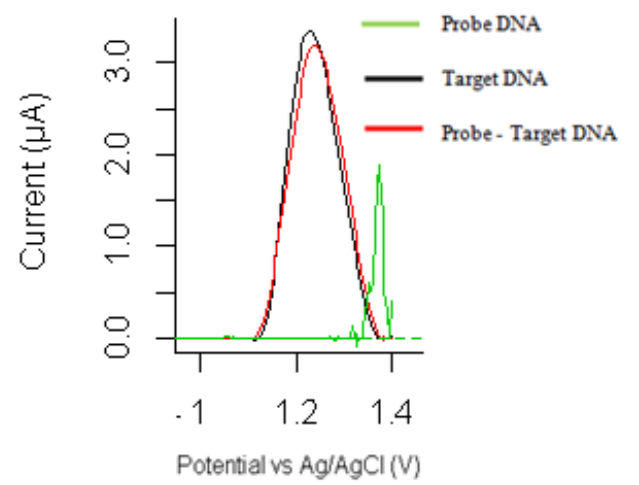

Figure 3. The difference in differential pulse voltammograms peak current for $20 \mu \mathrm{g} / \mathrm{mL}$ of probes DNA in acetate buffer, $20 \mu \mathrm{g} / \mathrm{mL}$ target DNA in phosphate buffer saline, and the hybridization probe - target DNA each $20 \mu \mathrm{g} / \mathrm{mL}$ in acetate buffer, using cerium modified SPCE. Measurement by using DPV, scan rate $0.008 \mathrm{~V} / \mathrm{s}$ in potential range of $-0.2 \mathrm{~V}$ to $+1.4 \mathrm{~V}$.

The guanine oxidation peaks are in the potential range of $0.9 \mathrm{~V}$ to $1.29 \mathrm{~V}$ [27]. Figure 3 shows that the guanine oxidation peaks are in the potential range of $1.20 \mathrm{~V}$ to $1.22 \mathrm{~V}$. The probe DNA does not show the peak of guanine oxidation, this is because the guanine base in the probe DNA has been replaced by inosine, which does not provide peak currents in the guanine potential area. DNA immobilization on the SPCE-Ce surface is based on electrostatic forces that occur through the phosphate backbone of DNA [25]. The HSAB theory has explained that hard Lewis acids will bind strongly to hard Lewis bases, in this case, cerium is a hard Lewis acid, whereas phosphate is a hard Lewis base so that both can bond very strongly.

The high oxidation peak current of the targeted guanine DNA is $3.25 \mu \mathrm{A}$ for a concentration of $20 \mu \mathrm{g} / \mathrm{mL}$, while the peak current in the probe-target DNA is $3.15 \mu \mathrm{A}$ with each concentration of $20 \mu \mathrm{g} / \mathrm{mL}$. The hybridization process starts when two DNA strands move with each other until the two meet, then alternate to start the formation of a double helix. Next, two strands go to the hybridization site by aligning the complementary base, then the DNA duplex begins to form [28]. The peak current generated from hybridization of the probe target DNA is lower than the target DNA peak current because in hybridization probe-target DNA are formed by double strands of DNA. Double-stranded DNA (dsDNA) provides a lower oxidation peak than target DNA in the form of single-stranded DNA. The nitrogen base in dsDNA seems to be hidden into the helix and the stiffness of this structure causes the nitrogen base to be far from the electrode surface, thus inhibiting the oxidation process [29].

\subsection{Biosensor current response to probe concentration, immobilization time, and hybridization time}

The phase of immobilization and hybridization are an important stage in biosensors. The probe is immobilized so that hybridization can occur with its complementary sequence of target DNA [30]. Specific hybridization between probes and target DNA was detected using an electrochemical transducer [27]. The current response to the concentration of the probe can be seen in Figure 4. 


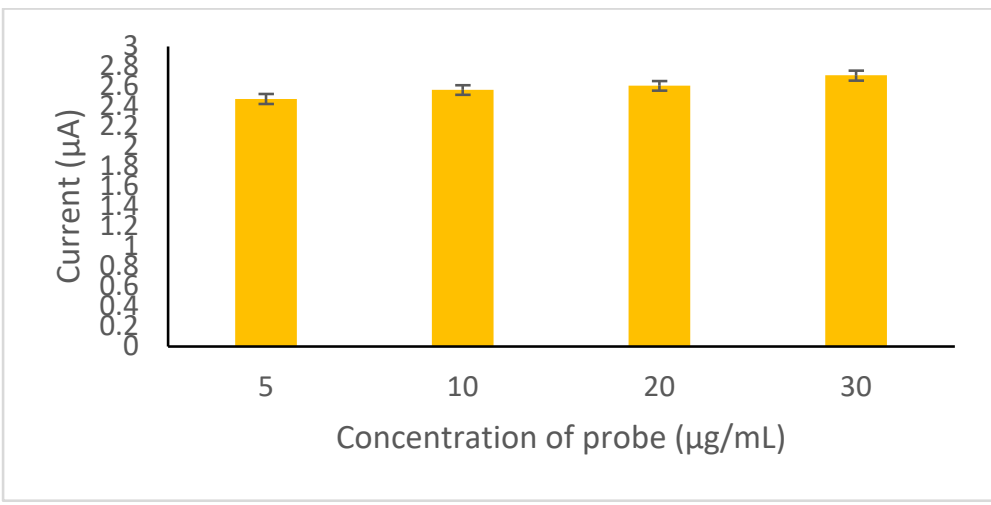

Figure 4. Determination of probe DNA concentration $(5.0,10.0,20.0,30.0 \mu \mathrm{g} / \mathrm{mL})$ against the peak of the guanine oxidation current. Determination of current uses differential pulse voltammetry, scan rate $0.008 \mathrm{~V} / \mathrm{s}$ in the potential range $-0.2 \mathrm{~V}$ to $+1.4 \mathrm{~V}$. The target concentration for hybridization is 5.0 $\mu \mathrm{g} / \mathrm{mL}$.

Figure 4 shows that the greater the concentration of probe DNA, the higher the guanine oxidation current generated from the probe hybridization process. This is in accordance with the Ilkovic equation which states that there is a linear relationship between current and concentration. The difference in peak current generated from each variation of the concentration of the probe did not differ much, because the target DNA concentration used for hybridizing was $5.0 \mu \mathrm{g} / \mathrm{mL}$.

Other factors that affect the quality and character of the peaks in the pulse voltammetry technique are the time of immobilization and hybridization. The time of immobilization was the time used by the SPCE-Ce surface to adsorb probes DNA. The hybridization time is the time that nitrogen bases are used in the probe DNA to interact with nitrogen bases from the target DNA. The current response generated from the time of immobilization and hybridization is shown in Figure 5.

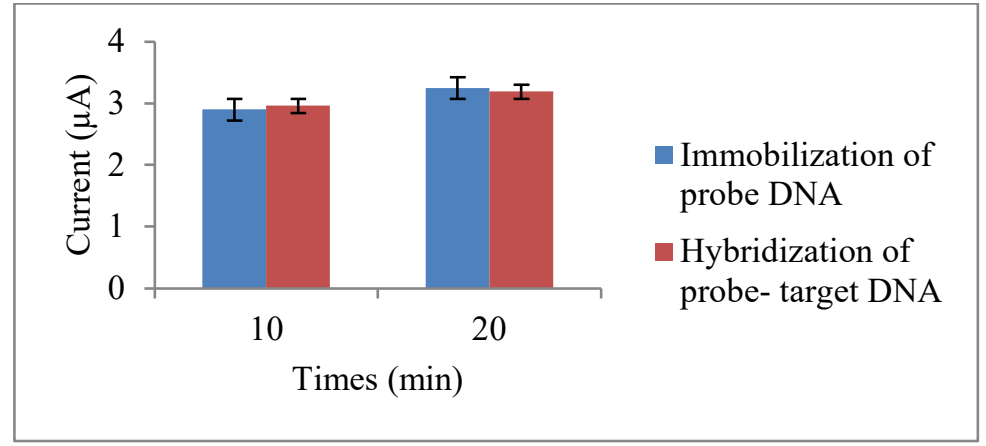

Figure 5. Determination of immobilization and hybridization times (10 and 20 minutes, respectively) to the peak of the guanine oxidation current.

The measurement results in Figure 5 show that the longer the immobilization time, the more the current increases because probes DNA are more adsorbed on the SPCE-Ce surface. 
The more probe DNA are adsorbed, that the more target DNA interacts with probe DNA. Therefore, the hybridization time used is longer, so that 20 minutes is chosen as the optimum time for both the immobilization and hybridization stages. Thus, the results of the optimization of the experimental conditions can be used to measure the current of variations in the concentration of target DNA.

\subsection{Calibration curve of various targeted DNA concentration}

The target DNA concentration variation was carried out at optimum conditions, namely probe concentration $30.0 \mu \mathrm{g} / \mathrm{mL}$, time of immobilization 20 minutes, hybridization time 20 minutes. Variations in target DNA concentrations to be measured in peak currents are 5.0, $10.0,15.0,20.0,25.0$, and $30.0 \mu \mathrm{g} / \mathrm{mL}$. High-current voltograms for variations in target concentration are shown in Figure 6A. Figure 6A explains that the peak of guanine oxidation increases with increasing target DNA concentration. Based on the data in Fig.6A, the line equation, $\mathrm{I}(\mu \mathrm{A})=0.0303$ [target] +3.947 with linearity $\left(\mathrm{R}^{2}\right) 0.9979$ shown in Figure $6 \mathrm{~B}$.
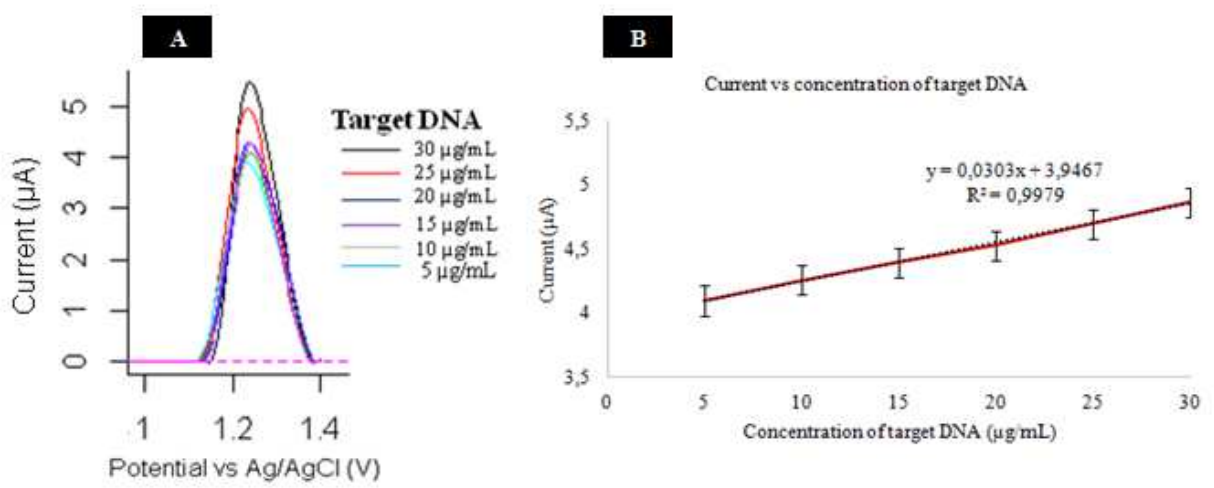

Figure 6. (A) Differential pulse voltammograms for hybridization between probe DNA and target DNA. Measurement by using DPV, scan rate $0.008 \mathrm{~V} / \mathrm{s}$ in a potential range of $-0.2 \mathrm{~V}$ to $+1.4 \mathrm{~V}$. (B) Linear relationship between peak current (Ip) with a concentration of target DNA.

Furthermore, linear line equations are used to calculate analytical parameters which include a limit of detection (LoD), limit of quantization (LoQ), sensitivity, and precision. Sensitivity testing on the electrochemical DNA biosensor method is expressed by the slope value of the linear regression equation, which is $0.0303 \mu \mathrm{g} / \mathrm{mL}$. While the determination of the LoD and LoQ values in this study obtained $1.44 \mu \mathrm{g} / \mathrm{mL}, 4.81 \mu \mathrm{g} / \mathrm{mL}$. Determination of precision is done by testing as many as 7 times repetition in one target DNA concentration which is in the linear range of the calibration curve, obtained a value of $98.99 \%$.

The previous research, the LoD value of electrochemical DNA biosensors using graphene as an SPCE modifier was obtained at $1.76 \mathrm{ng} / \mu \mathrm{L}$ [20], swine DNA in processed beef was obtained at $6.0 \mathrm{ng} / \mu \mathrm{L}$ and $4.0 \mathrm{ng} / \mu \mathrm{L}$ respectively using gold nanoparticles as a colometric sensor [17], [18], and DNA pork in meatballs was obtained at $0.58 \mu \mathrm{g} / \mathrm{mL}$ using AuNPbioconjugate in the SPCE-gold electrode [18]. 


\section{Conclusion}

Electrochemical DNA biosensors can be used to detect mitochondrial DNA Sus scrofa using cerium-modified SPCE. The guanine oxidation signal results from the hybridization probe-target DNA shows peak oxidation of guanine range potential to be at $1.20 \mathrm{~V}$ to $1.22 \mathrm{~V}$. Measurement of sensitivity, LoD, LoQ, and precision values were $0.0303 \mu \mathrm{g} / \mathrm{mL}, 1.44 \mu \mathrm{g} / \mathrm{mL}$, $4.81 \mu \mathrm{g} / \mathrm{mL}$, and $98.99 \%$. Then, the method can be used to determine sequence and concentrations of pig mtDNA in real samples.

\section{Acknowledgements}

The authors would like to thanks to the Ministry of Research, Technology, and Higher Education of Indonesia for supporting this research as Magister Research Scheme, No.2890/UN6.D/LT/2019.

\section{References}

[1] Badan Pengawas Obat dan Makanan, "Peraturan Kepala Badan Pengawas Obat dan Makanan Republik Indonesia Nomor 1 Tahun 2015 Tentang Kategori Pangan,” Jdih Bpom Ri, 2015.

[2] M. Baharuddin, "Problem sertifikasi halal produk pangan hewani," J. Asas, vol. 2, no. 1, pp. 1-10, 2010.

[3] A. Rohman, Sismindari, Y. Erwanto, and Y. B. Che Man, "Analysis of pork adulteration in beef meatball using Fourier transform infrared (FTIR) spectroscopy," Meat Sci., 2011.

[4] I. Giovannacci, C. Guizard, M. Carlier, V. Duval, J. L. Martin, and C. Demeulemester, "Species identification of meat products by ELISA," Int. J. Food Sci. Technol., 2004.

[5] B. Kuswandi, K. A. Cendekiawan, N. Kristiningrum, and M. Ahmad, "Pork adulteration in commercial meatballs determined by chemometric analysis of NIR Spectra," J. Food Meas. Charact., 2015.

[6] S. K. A. Manan, F. A. Rahman, and M. Sahri, Contemporary Issues and Development in the Global Halal Industry. 2017.

[7] G. Balizs et al., "Determination of osteocalcin in meat and bone meal of bovine and porcine origin using matrix-assisted laser desorption ionization/time-of-flight mass spectrometry and high-resolution hybrid mass spectrometry," Anal. Chim. Acta, vol. 693, pp. 89-99, May 2011.

[8] A. Szabó, H. Fébel, L. Sugár, and R. Romvári, "Fatty acid regiodistribution analysis of divergent animal triacylglycerol samples - A possible approach for species differentiation," J. Food Lipids, 2007.

[9] F. Lucarelli, G. Marrazza, A. P. F. Turner, and M. Mascini, "Carbon and gold electrodes as electrochemical transducers for DNA hybridisation sensors," Biosensors and Bioelectronics. 2004.

[10] W. N. Suryapratiwi, V. I. Paat, S. Gaffar, and Y. W. Hartati, "DNA biosensor for detection of Salmonella typhi from blood sample of typhoid fever patient using gold electrode modified by self-assembled monolayers of thiols," in AIP Conference Proceedings, 2017.

[11] A. A. Aida, Y. B. C. Man, C. M. V. L. Wong, A. R. Raha, and R. Son, "Analysis of raw meats and fats of pigs using polymerase chain reaction for Halal authentication," 
Meat Sci., 2005.

[12] H. D. Nguyen, T. A. Bui, P. T. Nguyen, O. T. P. Kim, and T. T. B. Vo, "The complete mitochondrial genome sequence of the indigenous i pig (Sus scrofa) in Vietnam," Asian-Australasian J. Anim. Sci., 2017.

[13] Y. Erwanto, M. Z. Abidin, A. Rohman, and Sismindari, "PCR-RFLP using BseDI enzyme for pork authentication in sausage and nugget products," Media Peternak., 2011.

[14] S. Maryam, S. Sismindari, T. J. Raharjo, Sudjadi, and A. Rohman, "Determination of Porcine Contamination in Laboratory Prepared dendeng Using Mitochondrial DLoop686 and cyt b Gene Primers by Real Time Polymerase Chain Reaction," Int. J. Food Prop., 2016.

[15] M. Bieliková, D. Pangallo, and J. Turňa, "Polymerase Chain Reaction - Restriction Fragment Length Polymorphism (PCR-RFLP) as a molecular discrimination tool for raw and heat-treated game and domestic animal meats," J. Food Nutr. Res., 2010.

[16] M. E. Ali, U. Hashim, S. Mustafa, and Y. B. C. Man, "Swine-Specific PCR-RFLP Assay Targeting Mitochondrial Cytochrome B Gene for Semiquantitative Detection of Pork in Commercial Meat Products," Food Anal. Methods, 2012.

[17] M. E. Ali, S. Mustafa, U. Hashim, Y. B. Che Man, and K. L. Foo, "Nanobioprobe for the determination of pork adulteration in burger formulations," J. Nanomater., 2012.

[18] M. E. Ali, U. Hashim, S. Mustafa, Y. B. Che Man, and K. N. Islam, "Gold nanoparticle sensor for the visual detection of pork adulteration in meatball formulation," J. Nanomater., 2012.

[19] N. I. A. Halid, S. A. Hasbullah, H. Ahmad, L. Y. Heng, N. H. A. Karim, and S. N. Harun, "Electrochemical DNA biosensor for detection of porcine oligonucleotides using ruthenium(II) complex as intercalator label redox," in AIP Conference Proceedings, 2014.

[20] Y. W. Hartati, A. A. Suryan, M. Agustina, S. Gaffar, and A. Anggraeni, "A Gold Nanoparticle-DNA Bioconjugate-Based Electrochemical Biosensor for Detection of Sus scrofa mtDNA in Raw and Processed Meat," Food Anal. Methods, vol. 12, pp. 2591-2600, 2019.

[21] R. R. Utomo, A. Suryanto, J. B. Pertanian, F. Pertanian, U. Brawijaya, and J. Timur, "PENGGUNAAN MULSA DAN UMBI BIBIT ( G4 ) PADA TANAMAN KENTANG ( Solanum tuberosum L . ) VARIETAS GRANOLA THE USE OF MULCH AND SEED TUBERS ( G4 ) IN POTATO PLANTS ( Solanum tuberosum L .) GRANOLA VARIETIES,” vol. 1, no. 1, pp. 9-15, 2013.

[22] N. T. Nguyet et al., "Highly sensitive DNA sensors based on cerium oxide nanorods," J. Phys. Chem. Solids, 2018.

[23] F. Charbgoo, M. Bin Ahmad, and M. Darroudi, "Cerium oxide nanoparticles: Green synthesis and biological applications," International Journal of Nanomedicine. 2017.

[24] N. F. Starodub and J. O. Ogorodnijchuk, "Immune Biosensor Based on the ISFETs for Express Determination of Salmonella typhimurium," Electroanalysis, 2012.

[25] R. Pautler, E. Y. Kelly, P. J. J. Huang, J. Cao, B. Liu, and J. Liu, “Attaching DNA to nanoceria: Regulating oxidase activity and fluorescence quenching," ACS Appl. Mater. Interfaces, 2013.

[26] U. Baroroh and M. Yusuf, "Basic of protein modeling using web server application," in Workshop on Basic Bioinformatics PT Biofarma, 2019.

[27] Y. W. Hartati, Biosensor elektrokimia untuk deteksi urutan spesifik DNA. Unpad Press, 2009. 
[28] P. De-Los-Santos-Álvarez, M. J. Lobo-Castañón, A. J. Miranda-Ordieres, and P. Tuñón-Blanco, "Electrochemistry of nucleic acids at solid electrodes and its applications," Electroanalysis. 2004.

[29] T. J. Schmitt and T. A. Knotts IV, "Thermodynamics of DNA hybridization on surfaces," J. Chem. Phys., 2011.

[30] M. L. Pedano and G. A. Rivas, "Adsorption and electrooxidation of nucleic acids at carbon nanotubes paste electrodes," Electrochem. commun., 2004. 